\title{
ORIGINAL ARTICLE \\ Twentieth-century changes in the genetic composition of Swedish field pea metapopulations
}

\author{
MW Leino ${ }^{1,2}$, E Boström ${ }^{3}$ and J Hagenblad ${ }^{2,3}$ \\ Landrace crops are formed by local adaptation, genetic drift and gene flow through seed exchange. In reverse, the study of \\ genetic structure between landrace populations can reveal the effects of these forces over time. We present here the analysis of \\ genetic diversity in 40 Swedish field pea (Pisum sativum L.) populations, either available as historical seed samples from the \\ late nineteenth century or as extant gene bank accessions assembled in the late twentieth century. The historical material \\ shows constant high levels of within-population diversity, whereas the extant accessions show varying, and overall lower, levels \\ of within-population diversity. Structure and principal component analysis cluster most accessions, both extant and historical, \\ in groups after geographical origin. County-wise analyses of the accessions show that the genetic diversity of the historical \\ accessions is largely overlapping. In contrast, most extant accessions show signs of genetic drift. They harbor a subset of the \\ alleles found in the historical accessions and are more differentiated from each other. These results reflect how, historically \\ present metapopulations have been preserved during the twentieth century, although as genetically isolated populations. \\ Heredity (2013) 110, 338-346; doi:10.1038/hdy.2012.93; published online 21 November 2012
}

Keywords: Pisum sativum; simple sequence repeats; population structure; landraces; aged DNA; seed exchange

\section{INTRODUCTION}

Knowing a crop's genetic diversity, within and between populations, and its level of stratification is a prerequisite for the successful collection and preservation of its genetic resources. The identification of geographical regions hosting maximum genetic variability can guide where to perform extensive collection missions, whereas genetically less diverse regions can be sampled more sparingly. Additionally, genetic population structure will reflect the amount of gene flow between populations. The study of genetic diversity can thus also reveal information regarding the extent of seed exchange networks in time and space.

The genetic diversity and evolution of field pea (Pisum spp.) global genetic resources have recently been studied with DNA markers (Baranger et al., 2004; Zong et al., 2009; Jing et al., 2010, 2012). These studies showed that the Pisum germplasm is structured into clades corresponding to taxonomic subdivisions, phenotypic traits and/or different end-use and geographical origin. Furthermore, it was shown that pea cultivars have a rather small pool of genetic diversity (Jing et al., 2010) and that some subgroups, such as European feed peas, have a very narrow genetic basis (Baranger et al., 2004). In contrast, genetic diversity in wild and landrace accessions was found to be much wider.

In spite of the recognition of landraces as genetic resources rich in variation and with valuable adaptive traits for certain areas, surprisingly little is known about the within-population diversity of pea landraces. Estimates of within-population diversity are beneficial for the calculation of population sizes for preservation of biodiversity in agricultural landscapes. In a recent survey of Swedish landrace crops, we found variable levels of genetic diversity in field pea landraces (Hagenblad et al., 2012). The sample size of this survey, however, was too small to make any conclusions regarding, for example, geographical differences in diversity or the effect of conservation status.

Peas have, alongside cereals, historically been the most important crop species in Sweden and have been cultivated since Neolithic time (Osvald, 1959; Hjelmqvist, 1979). In some of the earliest historical documents from Sweden, that is, law books from the fourteenth century, pea cultivation is mentioned. During the nineteenth century, peas were cultivated on more than $3 \%$ of Swedish farmland and regionally much more intensively. However, during the twentieth and twenty-first century, pea cultivation has declined (Leino and Nygårds, 2008; Swedish Board of Agriculture, 2011).

The oldest and traditional form of pea are field peas with pigmented flowers and seed testa, also known as gray peas. This trait is regulated by a single dominant gene, A (Mendel, 1866; Hellens et al., 2010). Swedish field pea has historically been extensively used for food, and the same cultivars could have the combined end-uses of food and animal feed (Bingefors et al., 1986; Leino and Nygårds, 2008). Until the early twentieth century, locally adapted landraces of field pea were almost solely cultivated. This contrasts with garden peas, where foreign cultivars have been used for several centuries. Plant improvement of field pea began in Sweden in 1891, and the first cultivars were released 10 years later (Åkerberg, 1951; Bingefors et al., 1986).

Although field peas were perhaps the field crop where landrace cultivation was retained the longest, cultivation of landrace field peas was more or less discontinued after the 1950s (Osvald, 1959; Bingefors et al., 1986). In spite of the general replacement of

${ }^{1}$ Swedish Museum of Cultural History, Julita, Sweden; ${ }^{2}$ FFM-Biology, Linköping University, Linköping, Sweden and ${ }^{3}$ Department of Biology, Norwegian University of Science and Technology, Trondheim, Norway

Correspondence: Dr J Hagenblad, IFM - Biology, Linköping University, SE-581 83 Linköping, Sweden.

E-mail: Jenny.Hagenblad@liu.se

Received 14 May 2012; revised 4 October 2012; accepted 5 October 2012; published online 21 November 2012 
landraces with commercial cultivars, landraces have been kept as heirloom crops by a few dedicated farmers, cultivated on a small scale and handed down from generation to generation (Leino and Nygårds, 2008). This enabled the plant breeders such as Stig Blixt at Weibullsholm, Non Government Organisations and the Nordic Genetic Resource Center (NordGen) to collect and preserve a relatively large number of field pea landraces (http://www.nordgen. org; Ingrid Rydberg, personal communication). Field pea (Pisum sativum L.) landraces collected and preserved in Sweden thus constitute an extraordinary exception to most Northern European landrace crops. In contrast with cereals preserved in genebanks, many Swedish field peas have a very short ex situ conservation history.

It is worth noting that in spite of a century of field pea commercial breeding and cultivar release, still in the early twenty-first century, when the Swedish national program for plant genetic resources (POM) launched a call for crop material preserved 'on farm', additional field pea landraces were found and could be collected (Leino and Nygårds, 2008). This is in strong contrast to cereals, where almost no landrace still under cultivation has been found since the formation of the Nordic Gene Bank in 1979.

Together with the extant material, an interesting complementary material can be found in the form of historical seed samples at the Swedish Museum of Cultural History. These historical samples were collected on Swedish farms in 1896, and have since the original harvest been stored in sealed glass containers with no handling or regeneration. Thus, the seeds are no longer viable. However, DNA in the aged peas is relatively intact and permits PCR amplification of single-copy nuclear genes (Leino et al., 2009). Collected before the advent of pea breeding, these historical samples offer a snapshot of the genetic diversity present during the height of field pea cultivation in Sweden and constitute a valuable reference material.

Taken together, two types of landrace field pea accessions with contrasting preservation history are available: historical material sampled in the nineteenth century and extant material cultivated on farm until they were donated to NordGen during the late twentieth and in some instances twenty-first century. A good geographical coverage of Sweden can be obtained with abundant accessions from four counties: Jämtland, Dalarna, Bohuslän and Skåne (Figure 1). We report here on the genetic analysis of these contrasting materials. Genetic studies of Swedish land race barley (Leino and Hagenblad, 2010), performed using historical material from the late nineteenth century, showed clear population structure within Sweden as a consequence of introduced seed and cultivation history. In the case of field pea, we have the possibility of not only analyzing the relationship of historical landrace populations, but also how these relationships have changed in populations and metapopulations over 100 years.

\section{MATERIALS AND METHODS}

\section{Plant material}

Extant material was provided by the Nordic Genetic Resource Center (NordGen). Historical seeds were taken from the KSLA (Royal Swedish Academy of Agriculture and Forestry) seed collection (Leino et al., 2009). These latter seeds have been stored in sealed glass containers in ambient temperatures since harvest in the late nineteenth century. The materials are summarized in Table 1.

DNA extraction and simple sequence repeat analysis

From each accession, DNA was isolated from eight individuals (seven individuals for accession NGB17879). For extant material, DNA was extracted from young leaves using the E-Z 96 Plant DNA Kit (Omega Bio-tek Inc., Norcross, GA, USA). Extraction of DNA from historical seeds was performed in a separate laboratory where DNA was isolated from the dry seed material using the FastDNA Spin Kit and the FastPrep Instrument (Qbiogene Inc, Carlsbad, CA, USA) and eluted in $100 \mu \mathrm{l}$ of the supplied buffer. In each extraction series, extraction blanks were performed in parallel.

Simple sequence repeat analysis was performed with 12 markers (AA278, AB109, AB71, AD73, AA200, AB122, AC58, AD147, AB130, AB141, AD83 and B14) from Loridon et al. (2005). Markers were chosen to have a high polymorphic information content value, amplify rather short fragments and be well distributed over the genome. PCRs were run as described in Leino et al. (2009). As a quality control, two markers were amplified in five independent amplifications in each of eight individuals, four extant and four historical to investigate the fidelity of genotyping in both types of material. Amplification products were analyzed by capillary gel electrophoresis and confocal laser scanning using an ABI $3130 \times 1$ Genetic Analyzer (Applied Biosystems, Foster City, CA, USA) and GeneMapper version 4.0.

\section{Statistical analysis}

Wright's $F_{\mathrm{ST}}$ (Wright, 1951) $\left(F_{\mathrm{ST}}=\left(H_{\mathrm{T}}-H_{\mathrm{S}} / H_{\mathrm{T}}\right)\right.$, where $H_{\mathrm{T}}$ is the expected heterozygosity in the populations combined and $H_{\mathrm{S}}$ is the average expected heterozygosity within each population), and Nei's $h\left(h=1-\Sigma\left(p_{i}^{2}\right)\right.$, where $p_{i}$ is the frequency of the $i$ th allele), were estimated according to Nei (1973) using purpose-written perl scripts. The $F_{\mathrm{ST}}$ significance values were determined by permutation tests (1000 permutations).

The software Structure v 2.2 (Pritchard et al., 2000; Falush et al., 2003) was used to analyze the results for geographic clustering. As peas were largely or completely homozygous, we therefore used a haploid setting, exchanging the few heterozygous loci with missing data. We further used a model with correlated allele frequencies among populations with no admixture. Nonamplifying markers were treated as missing data. The software was run with a burn-in length of 50000 iterations followed by 20000 iterations for estimating the parameters. This was repeated ten times for each $K$ (the number of predetermined clusters) until the likelihood values for the runs no longer improved. The software CLUMPP v 1.1.1 (Jakobsson and Rosenberg, 2007) was used to compare the results of individual runs and to calculate similarity coefficients and the average matrix of ancestry. In CLUMPP, the FullSearch algorithm was used for comparing runs with $K<4$, whereas the Greedy algorithm was used for higher Ks. The number of clusters observed in the data set was also evaluated by calculating $\Delta K$ according to Evanno et al. (2005). Graphical representation of the results was obtained using the DISTRUCT software v 1.1 (Rosenberg, 2004).

Principal component analysis (PCA) was carried out using the software R (R Development Core Team, 2007) using the prcomp command. Data were analyzed either on a population level (for all accessions) or on an individual level for each of the four counties: Skåne, Bohuslän, Dalarna and Jämtland. When analyzing populations, allele frequencies for each allele at each locus were calculated for the populations analyzed and treated as independent variables in the analysis. For analysis on the individual level, the number of alleles present in an individual $(0,1$ or 2$)$ for each allele at each locus were instead used as variables in the analysis.

\section{RESULTS}

We genotyped 12 simple sequence repeats markers in 8 individuals from each of 40 accessions of field pea. Of these, eight were from the region Skåne, nine from Bohuslän, eight from Dalarna, six from Jämtland and the remaining seven landraces originated from other parts of Sweden. We also included two field pea cultivars for comparison.

Two markers were repeatedly amplified five times in each of eight individuals, four extant and four historical. The repeatability of the genotyping was complete in both materials, with all five amplifications from the same individual yielding the same length of the amplification product. The amount of stutter bands was similar between amplifications in extant material and historical. DNA 

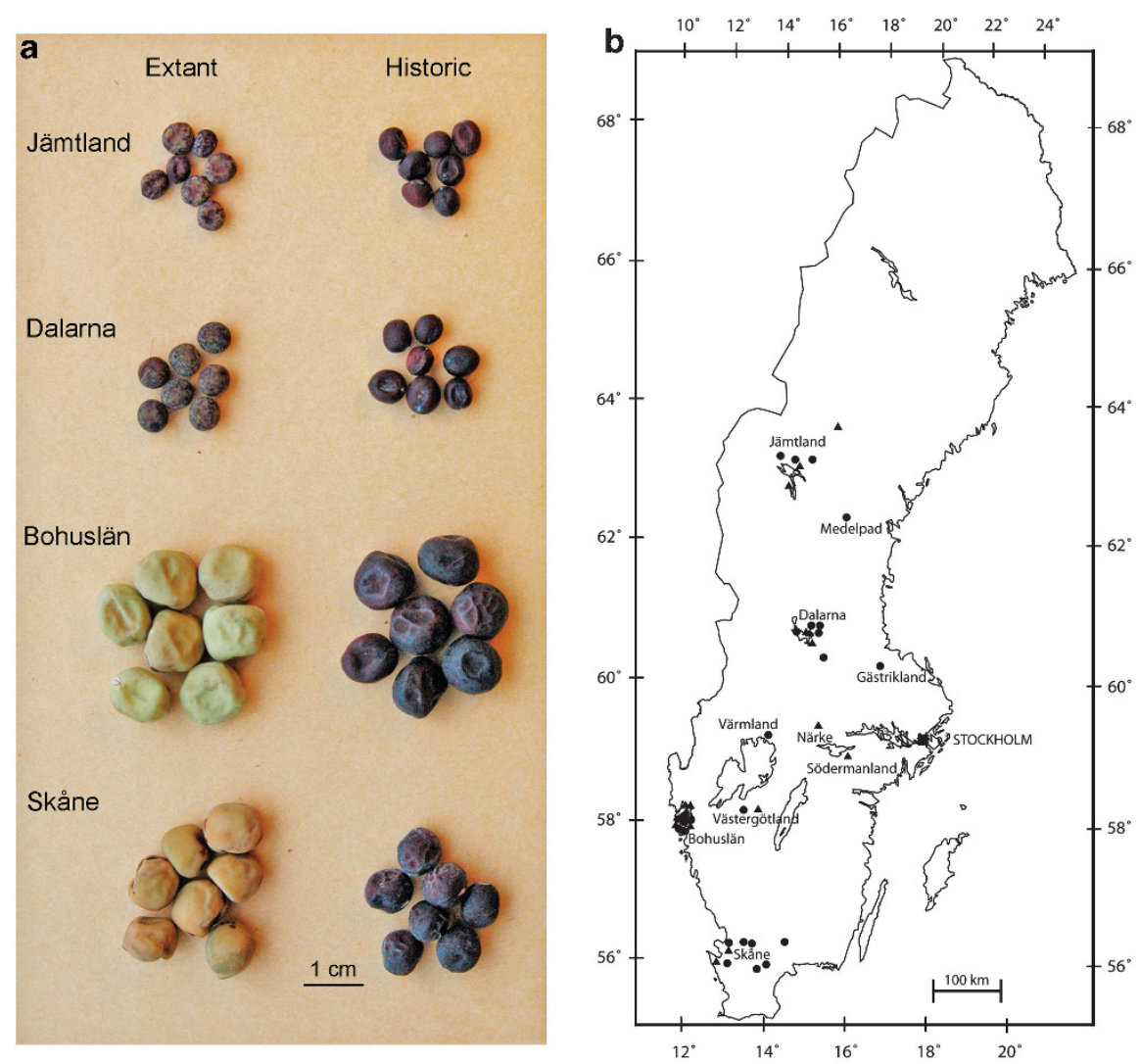

Figure 1 Swedish landrace field peas. (a) Typical seed morphology of extant and historical accessions from the four major districts. The dark color of the historical seeds is a result of oxidation during the 100 years of ambient temperature storage. (b) Map of Sweden indicating location of the 38 investigated landrace accessions and the four counties-Jämtland, Dalarna, Bohuslän and Skåne. Triangles denote historical accessions and circles denote extant accessions.

degradation in the historical material thus does not seem to give rise to spurious genetic variation when analyzing microsatellites.

The success rate differed between extant accessions, where DNA was extracted from fresh leaves or cotyledons, and historical accessions, where DNA was extracted from 116-year-old seeds. Extant accessions (mean $7.6 \%$ failed loci per individual) had a decidedly higher success rate than historical accessions (mean $24.2 \%$ failed loci per individual, $t$-test: $P \ll 0.001$ ), most likely as a result of poor DNA quality, although the presence of null alleles probably explains some of the amplification failures. Three of the historical accessions (NM1304, NM1332 and NM1391) had a very high proportion of missing data (defined as $>50 \%$ of the loci failing in more than half of the individuals), and these accessions were removed from further analysis. Treating missing data as null alleles, that is, an allele of its own, increased the genetic diversity of both historical and extant accessions. We therefore chose to omit them to be conservative with regard to our conclusions regarding genetic diversity.

We found highly variable levels of within-accession genetic diversity. Nei's $h$ varied from 0.109 in the extant accession NGB14637 to 0.629 in the historical accession NM1383, both from Bohuslän (Figure 2). The historical accessions had in general a higher genetic diversity than that of the extant accessions ( $h=0.504$ vs $h=0.274$, $t$-test: $P \ll 0.001)$. Pooling all accessions from each of the four main geographic regions (Skåne, Bohuslän, Dalarna and Jämtland) showed high levels of genetic diversity in each region ranging from $h=0.600$ in the combined set of Jämtland accessions to $h=0.719$ for the accessions from Bohuslän combined. Overall genetic diversity was higher, although not significantly so (paired $t$-test, $P=0.224$ ) than that found by Loridon et al. (2005) for the same markers in their set 1 of pea cultivars with different origin and end-use type.

Pairwise $F_{\mathrm{ST}}$ values between populations were generally high or very high and significant, ranging from 0.075 (nonsignificant) between the two accessions from Skåne NGB103590 and NGB14155

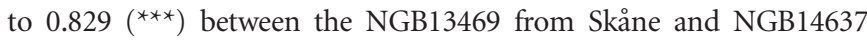
from Bohuslän (Figure 3 and Supplementary Table S1). Low and nonsignificant $F_{\mathrm{ST}}$ values were primarily found in comparisons between accessions from the same region. Several pairs of populations from Jämtland and Dalarna had low and nonsignificant $F_{\mathrm{ST}}$ values, whereas this was the case for only one within-region pairwise comparison each for Skåne and Bohuslän (Figure 3, Supplementary Table S1).

The high $F_{\mathrm{ST}}$ values seemed to be at least in part due to high between-accession variation. When all accessions from each of the four major geographic regions were pooled pairwise, $F_{\mathrm{ST}}$ values between regions were decidedly lower (although still significant), ranging from $0.074{ }^{* * *}$ ) between Jämtland and Dalarna to 0.142 ${ }^{* * *}$ ) between Jämtland and Bohuslän. Signs of isolation by distance could be detected, and regions more closely located geographically such as Jämtland-Dalarna and Skåne-Bohuslän (pairwise $F_{\mathrm{ST}}=0.087^{\star * *}$ ) generally had lower $F_{\mathrm{ST}}$ values than those more distantly located, although pairwise $F_{\mathrm{ST}}$ values were not completely correlated with distance.

We used the software Structure to explore the genetic diversity of the peas for signs of geographic structure. At $K=2$, one of 
Table 1 Origin and type of studied accessions

\begin{tabular}{|c|c|c|c|}
\hline Accession number & Designation & County of origin & Accession type \\
\hline NGB103517 & Jämtländsk grå & Jämtland & Landrace, extant (1981) \\
\hline NGB103076 & Jämtländsk grå & Jämtland & Landrace, extant (1979) \\
\hline NGB14642 & Lit & Jämtland & Landrace, extant (2001) \\
\hline NM1308 & Persåsen & Jämtland & Landrace, historical (1896) \\
\hline NM1396 & Risselös & Jämtland & Landrace, historical (1896) \\
\hline NM1315 & Rösta & Jämtland & Landrace, historical (1896) \\
\hline NGB103521 & WBH3521 (Rättvik) & Dalarna & Landrace, extant (1981) \\
\hline NGB17879 & Rättviksärt & Dalarna & Landrace, extant (2003) \\
\hline NGB17881 & Rättviks gråärt & Dalarna & Landrace, extant (2004) \\
\hline NGB17859 & Solleröärt & Dalarna & Landrace, extant (2003) \\
\hline NGB103525 & Pelusk från Dalarna & Dalarna & Landrace, extant (1981) \\
\hline NM1366 & Strumnäs & Dalarna & Landrace, historical (1896) \\
\hline NM1330 & Stumsnäs & Dalarna & Landrace, historical (1896) \\
\hline NM1391 & Forsängen & Dalarna & Landrace, historical (1896) \\
\hline NGB14637 & Bohusärt & Bohuslän & Landrace, extant (2001) \\
\hline NGB14638 & Brattebräcka & Bohuslän & Landrace, extant (2001) \\
\hline NGB14639 & Orust & Bohuslän & Landrace, extant (2001) \\
\hline NGB14153 & Solberga & Bohuslän & Landrace, extant (2001) \\
\hline NGB102222 & WBH2222 (Tjörn) & Bohuslän & Landrace, extant (1977) \\
\hline NM1383 & Cederslund & Bohuslän & Landrace, historical (1896) \\
\hline NM1292 & Tofta & Bohuslän & Landrace, historical (1896) \\
\hline NM1238 & Cederslund & Bohuslän & Landrace, historical (1896) \\
\hline NM1304 & Kasen & Bohuslän & Landrace, historical (1896) \\
\hline NGB14154 & Maglaby & Skåne & Landrace, extant (2001) \\
\hline NGB103590 & WBH3590 (Skararp) & Skåne & Landrace, extant (1981) \\
\hline NGB13469 & Stäme & Skåne & Landrace, extant (1997) \\
\hline NGB14155 & Skånsk gråärt & Skåne & Landrace, extant (2001) \\
\hline NGB101819 & WBH1819 (Norra Rörum) & Skåne & Landrace, extant (1973) \\
\hline NGB17873 & Puggor från Glimåkra & Skåne & Landrace, extant (2003) \\
\hline NM1388 & Nyrup & Skåne & Landrace, historical (1896) \\
\hline NM1332 & Tullstorp & Skåne & Landrace, historical (1896) \\
\hline NGB103488 & WBH3488 (Boltjärn) & Medelpad & Landrace, extant (1981) \\
\hline NGB17877 & Hedesunda & Gästrikland & Landrace, extant (2003) \\
\hline NGB17868 & Väse & Värmland & Landrace, extant (2002) \\
\hline NM1316 & Hammarby & Närke & Landrace, historical (1896) \\
\hline NM1231 & Äs & Södermanland & Landrace, historical (1896) \\
\hline NGB103518 & WBH3518 (Tollestorp) & Västergötland & Landrace, extant (1981) \\
\hline NM1306 & Kilagården & Västergötland & Landrace, historical (1896) \\
\hline NM1523 & Svalövs gröpärt 1918 & - & Cultivar, historical (1908) \\
\hline NGB101997 & Brioärt & - & Cultivar, extant \\
\hline
\end{tabular}

Year of collection for historical accessions and year of entry in NordGen for extant accessions are given.

the groups contained the two cultivar accessions, two accessions from Skåne and the accessions NGB17877 and NGB103488 from central Sweden. The latter is suspected of having a cultivar origin. The remaining accessions either clustered together or showed a mixed origin. At $K=3$, the non-cultivar cluster split into two groups containing either primarily northern accession or primarily more southern accessions, although the two groups did not show a complete correlation with geographic origin (Figure 4). Looking at only the historical accessions, the division between northern and southern accessions was complete (Supplementary Figure S1). Both the $\Delta K$-value and the CLUMPP $h$-value indicated that the genetic diversity was best described by three clusters (Supplementary Figure S2).

In addition to the high $\Delta K$ - and $h$-values at $K=3$, increased values were found for $K=7$ (Supplementary Figure S2). At this level, many of the populations showed a mixed origin, but the clusters identified showed clear geographical components with, for example, one cluster with peas from Jämtland, one with peas from Bohuslän and one with the three pea accessions from Rättvik in Dalarna (Supplementary Figure S3). Five of the seven accessions split off already at $K=2$ remained clustering at $K=7$.

Although most of the accessions clustered with those from the same geographic area, there were some accessions that consistently clustered away from their geographic region. For example, the accession NGB103488 claimed to originate from Boltjärn in Medelpad consistently clustered with the cultivars and accessions from Skåne almost $700 \mathrm{~km}$ away. The accession NGB14638 from Brattebräcka in Bohuslän only clustered with other accessions from Bohuslän at $K=2$, whereas at all higher $K$ s it instead clustered with peas from Jämtland and Dalarna. NGB17877 from Hedesunda in Gästrikland in mid-Sweden and NGB17859 from Sollerön in Dalarna were other accessions to cluster away from their given origin. These accessions also had seed morphologies very different from that typical of the respective geographical region. 


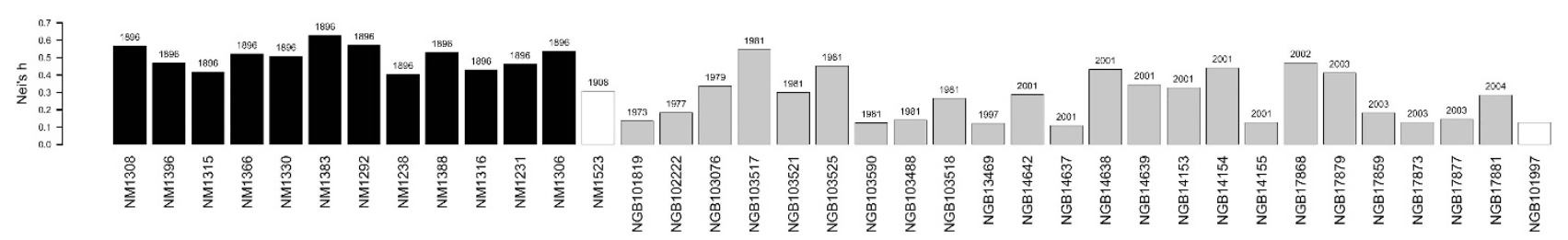

Figure 2 Diversity (Nei's $h$ ) in historical and extant accessions. Black bars denote historical landrace accessions, gray extant landrace accessions and white historical and extant cultivar accessions. Year of collection for historical accessions and year of entry in NordGen for extant accessions are given.

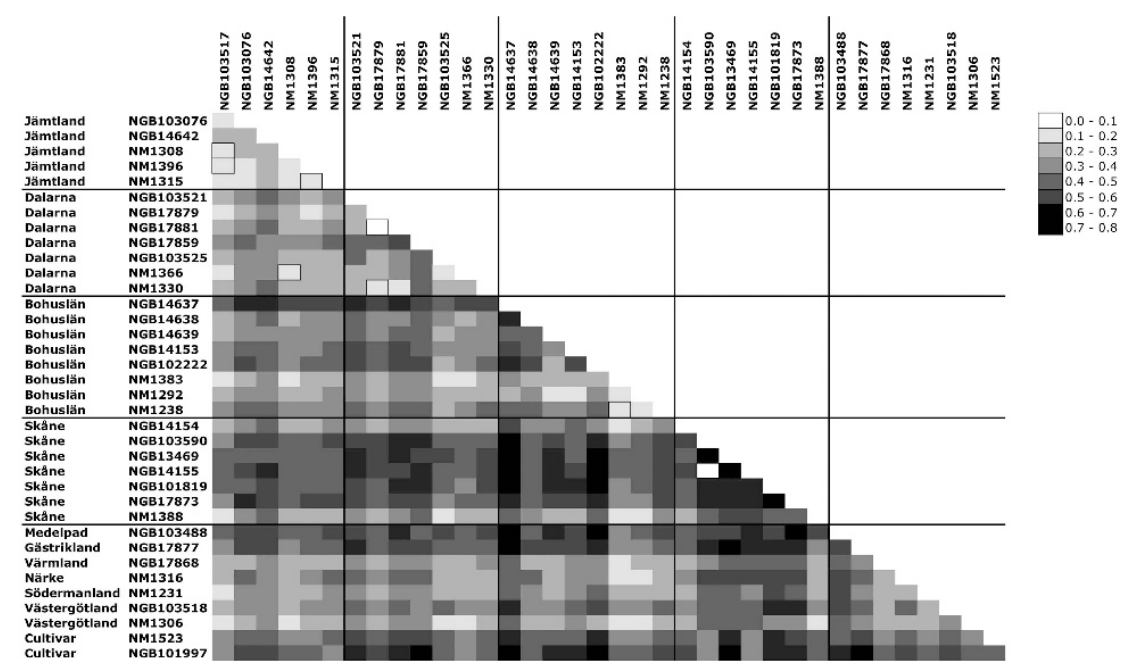

Figure 3 Pairwise $F_{\mathrm{ST}}$ values. Darker colors indicate higher $F_{\mathrm{ST}}$ values. Nonsignificant $F_{\mathrm{ST}}$ values are indicated by framed squares. None of the values $>0.2$ are nonsignificant.

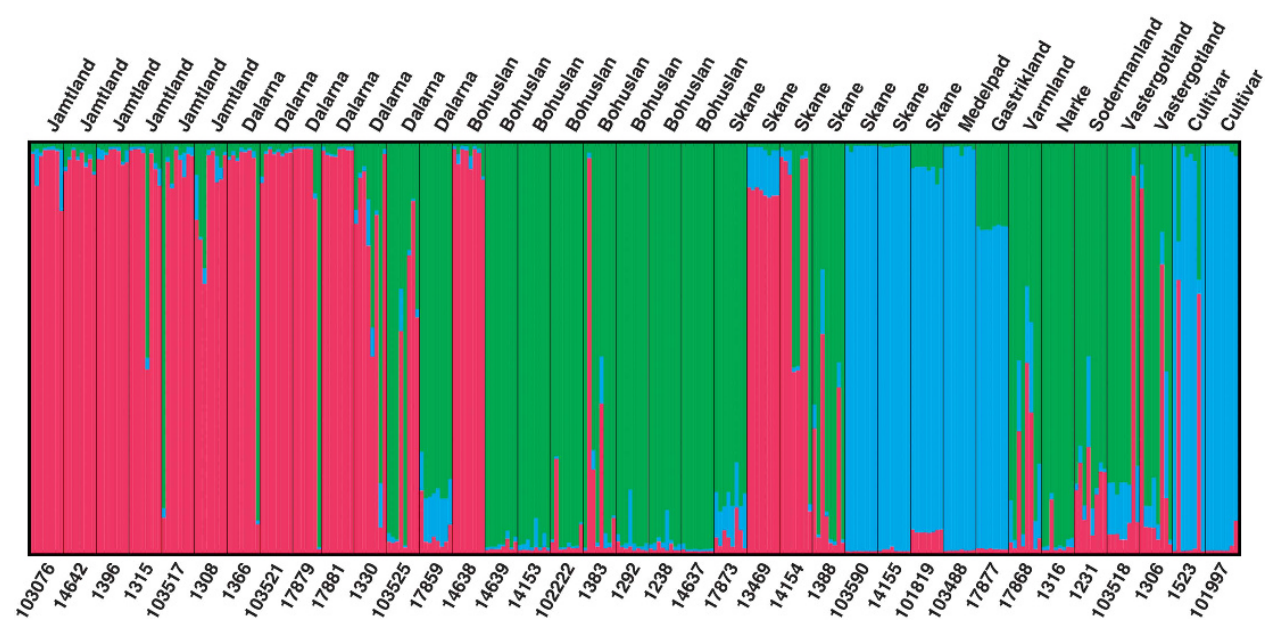

Figure 4 Graphical representation of STRUCTURE analysis for $K=3$.

We also performed PCA on the allele frequencies of each accession. The first principal component separated the cultivar accession 'Svalövs gröpärt' (NM1523) from all other accessions, whereas the second principal component separated NGB14638 from all other accessions (Figure 5a). Removing these two accessions led to a higher resolution between the remaining accessions. The overall clustering was very similar to that seen in the STRUCTURE analysis at $K=3$, with PC1 separating the blue from the green cluster and PC2 separating the red cluster from the blue and the green. Notable exceptions were the accessions NGB103518, NGB13469 and the mixed origin accession NGB103825 (Supplementary Figure S4). The accessions showed grouping according to geographic origin for the four main regions, although NGB17859 and 'Boltjärn' (NM1388) were located away from their geographic main cluster (Figure 5b). The second principal component separated accessions on a north-south geographic scale. The accessions from Jämtland showed the tightest clustering with all accessions located within a small well-defined space, whereas in particular the accessions from Skåne and Bohuslän were more scattered across the first two principal components (Figure 5b and Supplementary Figure S4).

PCA using the genotypes of each individual for the accessions from each of the four major regions showed a clear similarity in identity for individuals from the same accession. When comparing different accessions, the extant Jämtland accessions overlapped completely with 
a

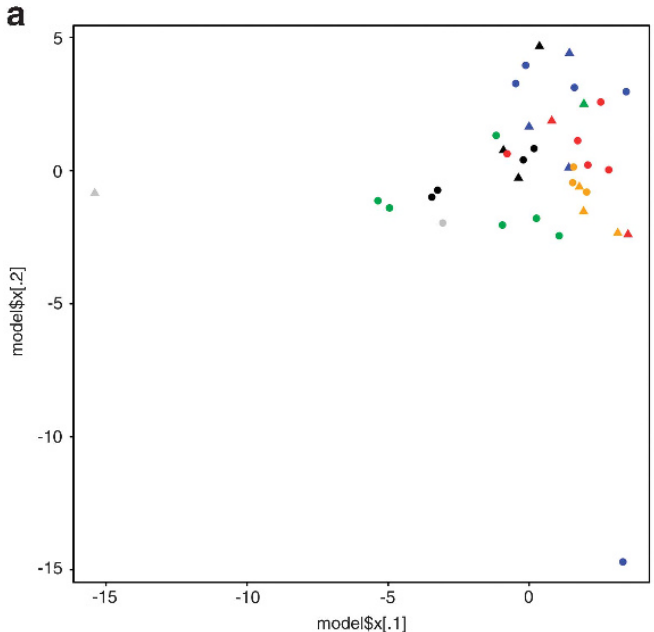

C

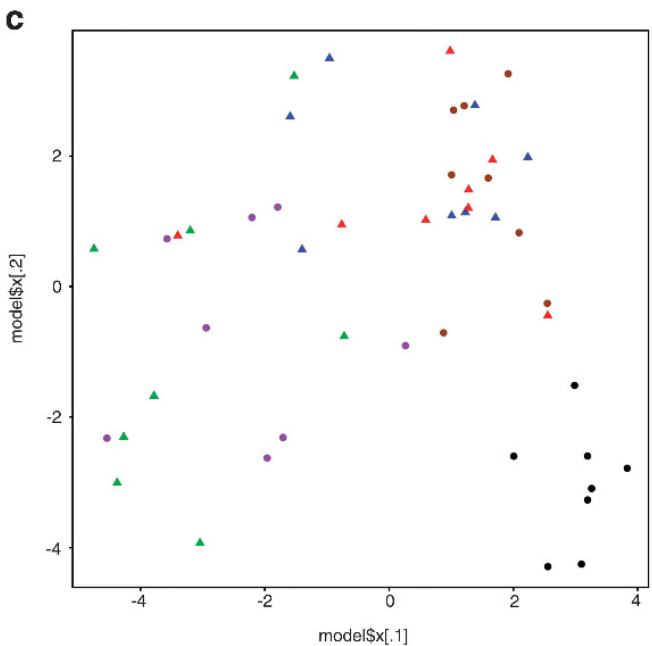

e

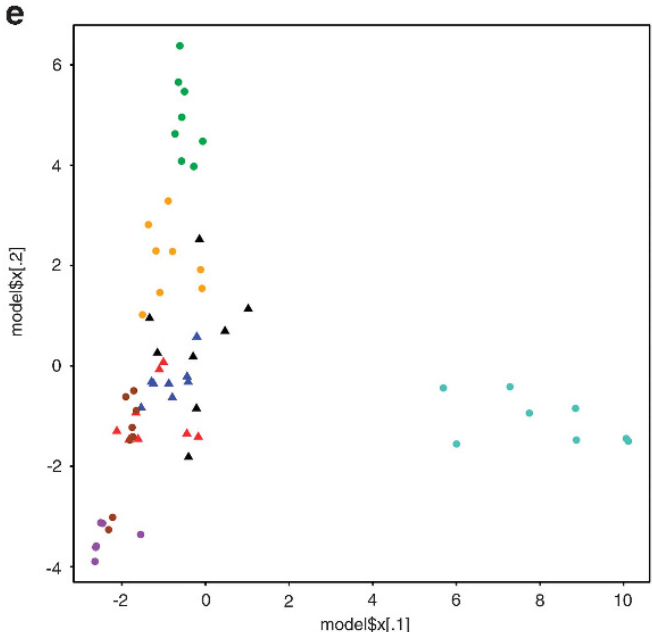

b

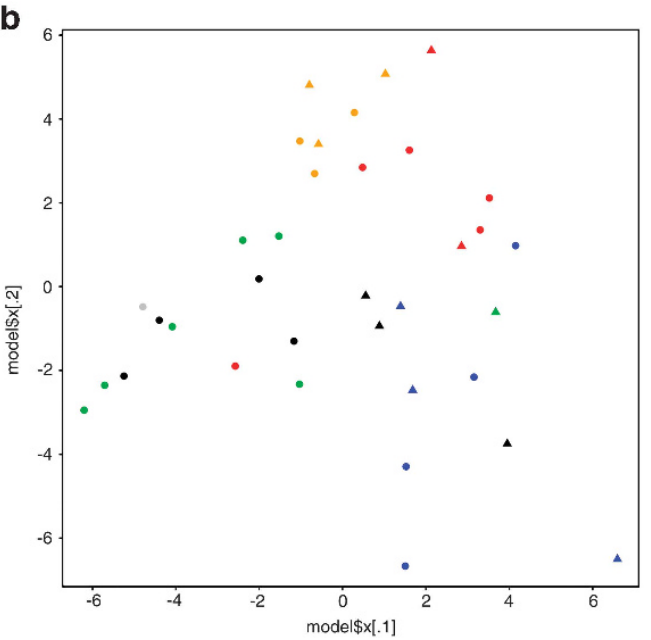

d

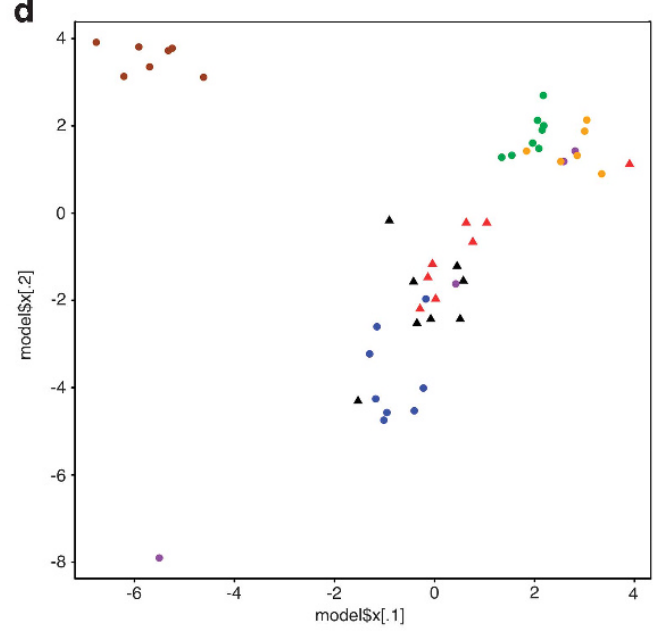

$\mathbf{f}$

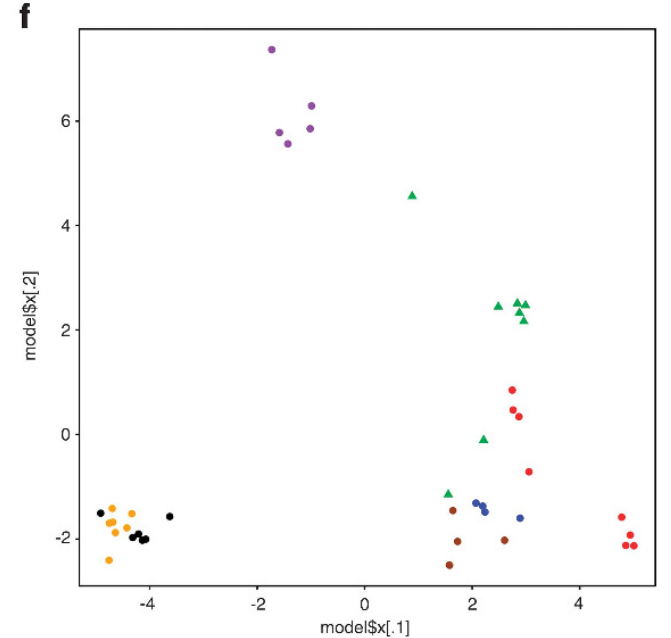

Figure 5 Associations between populations revealed by PCA. The circles denote extant accessions and triangles denote historical accessions. (a) All accessions (colors denote accessions from: green=Skåne, blue=Bohuslän, red=Dalarna, orange =Jämtland, black=other counties, gray =cultivar accessions); (b) all accessions except NM1523 NGB14638 (colors as in (a)); (c) associations between individuals of accessions from Jämtland (colors denote: green $=$ NM1308, blue $=$ NM1315, red $=$ NM1396, black $=$ NGB14642, brown $=$ NGB103076, purple $=$ NGB103517); (d) individuals of accessions from Dalarna (colors denote: green $=$ NGB103521, blue $=$ NGB103525, red $=$ NM1330, black $=$ NM1366, brown $=$ NGB17859, purple $=$ NGB17879, orange $=$ NGB17881); (e) individuals of accessions from Bohuslän (colors denote: green $=$ NGB102222, blue $=$ NM1238, red $=$ NM1292, black $=$ NM1383, brown $=$ NGB14153, purple $=$ NGB14637, orange $=$ NGB14639, aquamarine $=$ NGB14638); and $(f)$ individuals of accessions from Skåne (colors denote: green $=$ NM1388, blue $=$ NGB13469, red $=$ NGB14154, black $=$ NGB14155, brown $=$ NGB17873, purple $=$ NGB101819, orange $=$ NGB103590 . 
the historical material from the same region, with the exception of NGB14642 from Lit (Figure 5c). Among the Dalarna accessions the three accessions from Rättvik (NGB103521, NGB17881 and NGB18879) clustered tightly together. NGB103525, 'Pelusk från Dalarna', was the only extant accession to show overlap with the historical accessions. NGB17859 was again clearly separated from all other accessions (Figure 5d). Among the Bohuslän accessions the first principal component separated NGB14638 from all other accessions. NGB14639 and NGB14153 showed considerable overlap with the historical accessions, whereas NGB102222 and NGB14637 were genetically more distinct (Figure 5e). In the Skåne peas, the first principal component separated accessions into the two groups detected in the Structure analysis, whereas the second principal component separated the accession NGB101819 from all other accessions (Figure 5f).

To further explore regional diversity, we compared the number of alleles present in historical and extant accessions in Jämtland (with large population overlap in the PCA) and Bohuslän (where historical and extant population show considerable separation), the two regions where we had comparable numbers of historical and extant populations. In both regions, there were more alleles present in only historical populations (34.9\% and $46.6 \%$ for Jämtland and Bohuslän, respectively) than in only extant populations $(25.5 \%$ and $20.4 \%$ for Jämtland and Bohuslän, respectively), and the extant genetic diversity was primarily a subset of the historical populations $(74.5 \%$ and $79.6 \%$ for Jämtland and Bohuslän, respectively).

\section{DISCUSSION}

Population genetic data can reveal patterns of geographic spatial subdivision. Such patterns develop slowly over long periods of time through the actions of genetic drift, and to a certain extent selection, in populations with limited migratory exchange. Using a limited number of genetic markers, we show that extant Swedish field pea accessions constitute genetically distinct populations, with in many cases clear geographic clustering. Although crop species have spread across the world as recently as in the past 10000 years, geographical structure has been observed on a continental scale in pea (Jing et al., 2010, 2012) as well as in other species such as barley (Malysheva-Otto et al., 2006; Jones et al., 2011), maize (van Heerwaarden et al., (2011)) and einkorn wheat (Oliveira et al., 2011). On a national scale, reports on geographical structure among pea landraces are rare. One exception is China, where Zong et al. (2008) could classify pea accessions into at least three geographically distinct clusters.

The pea accessions investigated in this study showed the highest statistical support for grouping into three clusters, with one cluster for accessions with a cultivar origin and two clusters with a reasonably strong geographic division. It has, however, been recommended that other orders of clustering than the one with the highest statistical support are also evaluated in the light of the species biology and evolutionary history (Pritchard et al., 2000, Nordborg et al., 2005; Lawson Handley et al., 2007; Pritchard et al., 2010). A locally high statistical support was also found for $K=7$ clusters that, to a large extent, divided the accessions into geographically well-defined groups, with many clusters consisting primarily of accessions from the same county and nearby counties and most accessions from the same county falling into the same cluster. It should, however, be noted that the results should not be interpreted literary as three (or seven) random-mating populations but rather be seen as a tool to describe and explore the data.

Jämtland peas tend to be genetically more homogeneous than peas from other counties, and of the eight nonsignificant $F_{\mathrm{ST}}$ values found, three were between pairs of Jämtland accessions, including both extant and historical accessions. Jämtland was the part of Sweden where farmers continued the longest to prefer and cultivate landrace gray peas instead of commercial cultivars (Åkerberg, 1951). Our results here confirm the results of Hagenblad et al. (2012) that extant accessions from this area have both retained a high level of withinaccession genetic diversity and remained genetically similar compared with the nineteenth-century peas from the same area. Peas from the county Dalarna are morphologically very similar to the peas from Jämtland and genetically closely related, often clustering together in the Structure analysis and also showing considerable similarity along the second principal component in the PC analysis. The only pairwise comparison between accessions from different counties to give a nonsignificant $F_{\mathrm{ST}}$ value was between a pair of accessions from Jämtland and Dalarna, respectively. The three accessions from the municipality Rättvik proved to be particularly similar as could be expected as they reportedly have all been collected on the same farm, although at different time points.

Some accessions deviated clearly from the expected geographical clustering. At $K=3$, NGB103488 from Medelpad and NGB17877 from Gästrikland clustered with the group consisting of landraces from Skåne and cultivars, whereas NGB17859 from Dalarna clustered in the group with accessions from primarily Bohuslän. Probably the curating farmers of these heritage peas have at some point received or moved material from an unknown original location to the place of collection. Similar to our previous study (Hagenblad et al., 2012), the historical material was more consistent in geographical clustering. During the twentieth century, the seed trade and mobility of farmers and seed increased leading to the overstamping of historical geographical landrace patterns. This kind of observation has also been made with historical and extant European barley landraces (Lister et al., 2009). Our results further stress the importance of historical collections as a reference material for population genetic studies of extant landraces.

The two cultivars included in this study clustered consistently with accessions from Skåne in Southern Sweden as well as NGB103488 and NGB17877. In the PC analysis, the historical cultivar NM1523, Svalövs gröpärt, was markedly different from all other cultivars (Figure 5b). This cultivar was one of the first released cultivars in Sweden and was developed by pedigree selection of the pea 'Early Britain' around 1900. As can be expected, it has a lower genetic diversity than the other historical accessions (although higher than many extant landraces). The second cultivar 'Brio' is the result of a crossing between the soup pea (white-flowering) cultivar 'Torsdags II' and pedigree selections from 'Early Britain' (Åkerberg, 1951). The clustering of some extant landrace accessions with the two cultivars tentatively suggests a possible cultivar origin of these.

Although the cultural heritages of some peas have been lost during the past century, many of the extant landraces have retained the genetic heritage of their geographic region. As in our previous study (Hagenblad et al., 2012), we detect an overall high level of genetic diversity in the historical accessions, but a much more varying level of genetic diversity in the extant accessions. However, genebank accessions collected across several decades showed no consistent loss of genetic diversity, and we found both high- and low-level genetic diversity in different accessions collected at the same time. In contrast, loss of genetic diversity in pea accessions during genebank maintenance has previously been reported in a study of Czechoslovak pea landraces and cultivars (Cieslarová et al., 2010). The low-diversity NordGen accessions can be because of either low diversity of the source populations or the sampling procedures during the genebank 
donation. In the case of NGB14637 from Skåne, one of the accessions with the lowest diversity, we know from its entry in NordGen that only 11 seeds of the accession were donated (NordGen).

Landraces are often described as dynamic populations, altering in composition over time by seed exchange and, in the case of outbreeding species, pollen flow (Camacho-Villa et al. 2005). Alvarez et al. (2005) use the term metapopulations to describe how landrace populations within a defined geographical or morphological frame share and exchange genetic material. Genetic diversity studies of barley landraces in Sardinia (Papa et al., 1998; Rodriguez et al., 2012) and Ethiopia (Demissie et al. 1998) concluded that landraces in these areas were influenced by frequent seed exchange, resulting in high within-population diversity and differentiation between populations that was sometimes difficult to detect. In our case, some metapopulations could be suggested, for example, extant and historical peas from Jämtland and the historical peas in Dalarna and Bohuslän.

Historical accessions showed lower genetic differentiation than their contemporary counterparts from the same region, with both lower $F_{\mathrm{ST}}$ values and a higher overlap of populations in the PCA results (Figure 5). For example, in Bohuslän (Figure 5d), the three historical accessions were largely overlapping in the PCA and cluster together in the STRUCTURE analysis, although pairwise $F_{\text {ST }}$ values were in some cases significant. We suggest that historical seed exchange networks reduced the level of population differentiation and promoted high local agrobiodiversity. The importance of functional seed exchange networks for diversity conservation has recently been reviewed by Thomas et al. (2011) and Pautasso et al. (2012).

In contrast, many extant populations separate into more isolated clusters as seen by high $F_{\mathrm{ST}}$ values and low overlap of individuals in PCA (Figure 5). The extant material, collected many decades after the historical accessions, constitutes a subset of the historical genetic diversity. With the breakdown of traditional farming and its associated seed exchange networks during the twentieth century, landrace cultivation and trading became a marginalized practice. The development of commercial pea cultivars also led to a much-reduced demand for landrace peas, thus removing an important component of functioning seed exchange networks (Åkerberg, 1951).

The more marginalized cultivation of gray peas during the twentieth century with decreased seed exchange and consequently smaller effective population sizes resulted in the increased genetic drift particularly noticeable in the Bohuslän accessions (Figure $5 \mathrm{~d}$ ). The accessions from Bohuslän come from a very isolated area of the islands Orust and Tjörn, and the farms where the accessions were collected are separated by only a few kilometers of distance. Nevertheless, these farmers seem to have preserved their landraces independently and with little seed exchange. Notably, at least seven additional accessions from the same areas have been preserved (NordGen, personal communication). These may well constitute an additional genetic resource with unique genetic profiles for each accession.

Landrace peas constitute, in addition to being part of the cultural heritage, a genetic resource for future plant improvement. If efforts should be made to recover even more landraces, it is of interest to know where to search for new landraces to maximize the novel genetic diversity. The Structure analysis suggests that the number of pea populations in Sweden, at least those that can be detected with the present markers, is low. However, further analysis of subsets of data shows a more detailed picture with distinct subgroupings of accessions from the same geographic areas. As the highest level of resolution, we analyzed the principal components of genetic data from only individuals from the same county and found that each accession indeed had its own distinct genetic signature even at this geographic scale. This strongly suggests that additional genetic resources of field pea can still be discovered and that valuable genetic contributions can also be made from new accessions from previously densely sampled regions.

\section{DATA ARCHIVING}

Genotype data have been submitted to Dryad: doi:10.5061/ dryad.92p3p.

\section{CONFLICT OF INTEREST}

The authors declare no conflict of interest.

\section{ACKNOWLEDGEMENTS}

We thank Fredrik Ottosson at NordGen for help with seed material and passport data. This work was funded by the Lagersberg foundation, the Swedish Research Council for Environment, Agricultural Sciences and Spatial Planning (FORMAS) and the Swedish Board of Agriculture.

Åkerberg E (1951). Trindsäd. In: Åkerman Å, Nilsson F, Sylvén N, Fröier K (eds). Svensk växtförädling I: Stockholm 233-274.

Alvarez N, Garine E, Khasah C, Dounias E, Hossaert-McKey M, McKey D (2005). Farmers' practices, metapopulation dynamics, and conservation of agricultural biodiversity onfarm: a case study of sorghum among the Duupa in sub-sahelian Cameroon. Bio Conserv 121: 533-543.

Baranger A, Aubert G, Arnau G, Lainé AL, Deniot G, Potier J et al. (2004). Genetic diversity within Pisum sativum using protein and PCR-based markers. Theor App/ Genet 108: 1309-1321.

Bingefors S, Johansson N, Rydberg I (1986). Improved field pea cultivars for modern farming. In: Olsson G (ed) Svalöf 1886-1986. Research and Results in Plant Breeding. LT: Stockholm, pp 185-195.

Camacho-Villa TC, Maxted N, Scholten M, Ford-Lloyd B (2005). Defining and identifying crop landraces. Plant Gen Res 3: 373-384.

Cieslarová J, Smýkal P, Dočkalová Z, Hanáček P, Procházka S, Hýbl M et al. (2010). Molecular evidence of genetic diversity changes in pea (Pisum sativum L.) germplasm after long-term maintenance. Genet Res Crop Evol 58: 439-451.

Demissie A, Bjørnstad $\AA$, Kleinhofs A (1998). Restriction fragment length polymorphism in landrace barleys from Ethiopia in relation to geographic, altitude, and agro-ecological factors. Crop Sci 38: 237-243.

Evanno G, Regnaut S, Goudet J (2005). Detecting the number of clusters of individuals using the software STRUCTURE: a simulation study. Mol Ecol 14: 2611-2620.

Falush D, Stephens M, Pritchard JK (2003). Inference of population structure using multilocus genotype data: linked loci and correlated allele frequencies. Genetics 164 : 1567-1587

Hagenblad J, Zie J, Leino MW (2012). Exploring the population genetics of genebank and historical landrace varieties. Genet Res Crop Evol 59: 1185-1199.

Hellens RP, Moreau C, Lin-Wang K, Schwinn KE, Thomson SJ, Fiers MWEJ et al. (2010). Identification of Mendel's white flower character. PLOS One 5: e13230.

Hjelmqvist H (1979). Beiträge zur Kenntnis der prähistorischen Nutzpflantzen in Schweden. Opera Bot 47: 1-58.

Jakobsson M, Rosenberg NA (2007). CLUMPP: a cluster matching and permutation program for dealing with label switching and multimodality in analysis of population structure. Bioinformatics 23: 1801-1806.

Jing R, Vershinin A, Grzebyta J, Shaw P, Smýkal P, Marshall D et al. (2010). The genetic diversity and evolution of field pea (Pisum) studied by high throughput retrotransposon based insertion polymorphism (RBIP) marker analysis. BMC Evol Biol 10: 44

Jing R, Ambrose MA, Knox MR, Smykal P, Hybl M, Ramos Á et al. (2012). Genetic diversity in European Pisum germplasm collections. Theor App/ Genet 125: 367-380.

Jones H, Civán̆ P, Cockram J, Leigh FJ, Smith LMJ, Jones MK et al. (2011). Evolutionary history of barley cultivation in Europe revealed by genetic analysis of modern landraces. BMC Evol Biol 11: 320

Lawson Handley LJ, Manica A, Goudet J, Balloux F (2007). Going the distance: human population genetics in a clinal world. Trends Genet 23: 432-439.

Leino M, Nygårds L (2008). Puggor och pelusker - svenska lokalsorter av ärt. Svensk Botanisk Tidskrift 102: 153-162.

Leino MW, Hagenblad J, Edqvist J, Karlsson Strese E-M (2009). DNA preservation and utility of a historic seed collection. Seed Sci Res 19: 125-135.

Leino MW, Hagenblad J (2010). 19th century seeds reveal the population genetics of landrace barley (Hordeum vulgare). Mol Biol Evol 27: 964-973.

Lister DL, Thaw S, Bower MA, Jones H, Charles MP, Jones G et al. (2009). Latitudinal variation in a photoperiod response gene in European barley: insight into the dynamics of agricultural spread from 'historic' specimens. J Arch Sci 36: 1092-1098. 
Loridon K, McPhee K, Morin J, Dubreuil P, Pilet-Nayel ML, Aubert G et al. (2005). Microsatellite marker polymorphism and mapping in pea (Pisum sativum L.). Theor App/ Genet 111: 1022-1031.

Malysheva-Otto LV, Ganal MW, Röder MS (2006). Analysis of molecular diversity, population structure and linkage disequilibrium in a worldwide survey of cultivated barley germplasm (Hordeum vulgare L.). BMC Genet 7: 6 .

Mendel G (1866). Versuche über Pflanzen-Hybriden. Verh. Naturforsch. Ver. Brünn 4: 3-47.

Nei M (1973). Analysis of gene diversity in subdivided populations. Proc Natl Acad Sci USA 70: 3321-3323.

Nordborg M, Hu TT, Ishino Y, Jhaveri J, Toomajian C, Zheng H et al. (2005). The pattern of polymorphism in Arabidopsis thaliana. PLOS Biol 3: e196.

Oliveira HR, Jones H, Leigh F, Lister DL, Jones MK, Peña-Chocarro L (2011). Phylogeography of einkorn landraces in the Mediterranean basin and Central Europe: population structure and cultivation history. Archaeol Anthropol Sci 3: 327-341.

Osvald H (1959). Ákerns nyttoväxter. Sv litteratur: Stockholm.

Papa R, Attene G, Barcaccia G, Ohgata A, Konishi T (1998). Genetic diversity in landrace populations of Hordeum vulgare L. from Sardinia, Italy, as revealed by RAPDs, isozymes and morphophenological traits. Plant Breed 117: 523-530.

Pautasso M, Aistara G, Barnaud A, Caillon S, Clouvel P, Coomes OT et al. (2012). Seed exchange networks for agrobiodiversity conservation. A review. Agron Sustain Dev doi:10.1007/s13593-012-0089-6

Pritchard JK, Stephens M, Donnelly P (2000). Inference of population structure using multilocus genotype data. Genetics 155: 945-959.
Pritchard JK, Wen X, Falush D (2010). Documentation for structure software: Version 2.3. Available from. http://pritch.bsd.uchicago.edu/software.html.

R Development Core Team (2007). R: A language and environment for statistical computing. R Foundation for Statistical Computing, Vienna, Austria. ISBN 3900051-07-0, URL. http://www.R-project.org.

Rodriguez M, Rau D, O'Sullivan D, Brown AH, Papa R, Attene G (2012). Genetic structure and linkage disequilibrium in landrace populations of barley in Sardinia. Theor Appl Genet 125: 171-184.

Rosenberg NA (2004). Distruct: a program for the graphical display of population structure. $\mathrm{Mol}$ Ecol Notes 4: 137-138.

Swedish Board of Agriculture (2011). Agriculture in Figures - Years 1866-2007. Jönköping, Sweden.

Thomas M, Dawson JC, Goldringer I, Bonneuil C (2011). Seed exchanges, a key to analyze crop diversity dynamics in farmer-led on-farm conservation. Genet Res Crop Evol 58: 321-338.

van Heerwaarden J, Doebley J, Briggs WH, Glaubitz JC, Goodman MM, Gonzalez JJS et al. (2011). Genetic signals of origin, spread and introgression in a large sample of maize landraces. Proc Natl Acad Sci USA 108: 1088-1092.

Wright S (1951). The genetical structure of populations. Ann Eugen 15: 323-354.

Zong X, Redden RJ, Liu Q, Wang S, Guan J, Liu J et al. (2009). Analysis of a diverse global Pisum sp. collection and comparison to a Chinese local P. sativum collection with microsatellite markers. Theor Appl Genet 118: 193-204.

Zong X-X, Guan J-P, Wang S-M, Liu Q-C (2008). Genetic diversity among Chinese pea (Pisum sativum L.) landraces as revealed by SSR markers. Acta Agron Sin 34: 1330-1338.

Supplementary Information accompanies the paper on Heredity website (http://www.nature.com/hdy) 